\title{
LEAF LITTER DECOMPOSITION IN LARGE RIVERS: THE CASE OF THE RIVER GARONNE
}

\author{
E. Chauvet \\ Centre d'Ecologie des Systemes Aquatiques Continentaux (CNRS-UPS) \\ 29, rue Jeanne Marvig. 3 1055 Toulouse Cedex. France.
}

Keywords: Decomposition, leaf litter, large river, shredders, oligochaetes, bacteria, fungi.

\section{SUMMARY}

Recent investigations tend to demonstrate that the input of leaf litter from riparian vegetation, and its subsequent decomposition in water, are not only representative of small streams, but also of mid- to large-sized rivers. A review of different studies from the River Garonne (7th-order) points out the main traits of leaf litter decomposition, including the implication of microorganisms and invertebrates as well as the influence of environmental factors. When compared to a 3rd-order mountain stream, the River Garonne exhibited lower decomposition rates of the leaf species considered. Densities and biomass of invertebrates and the proportion of shredders associated with the decomposing leaf litter were higher in the large river. Likewise, microfungi appeared to play an important role in leaf litter decomposition in the River Garonne. Fungal biomass attained peaks of 5-10\% of detrital carbon and accounted on average for $96 \%$ of the total microbial (fungal plus bacteria]) biomass in leaf litter. Such a biomass was similar to those reported for leaf litter decomposing in headwaters. Therefore differences in breakdown capacities could not be attributed to differences in either invertebrate community structure or microbial activity. The limitation of abiotic fragmentation couid instead be responsible for slower breakdown in the large river, although direct evidence to support the hypothesis is lacking. At a larger scale, the physical heterogeneity of the River Garonne floodplain appears to induce large discrepancies in breakdown rates, like observed both between and within aquatic and terrestrial habitats.

\section{INTRODUCTION}

The importance of terrestrial leaf litter for the functioning of stream ecosystems has been documented by a number of studies over the last four decades (HYNES, 1963; CUMMINS et al., 1989). The River Continuum Concept emphasizes the decreasing importance of leaf litter input as a carbon source for the stream food web as the stream channel gets larger and other sources produced within the stream are made available (VANNOTE et al., 1980). It is not surprising, therefore, that the number of studies on leaf litter input to streams is inversely related to the size of the stream, namely the stream order, as shown by reviews of the literature on the subject (WEIGELHOFER \& WARINGER, 1994; BENFIELD, 1997: and other references). For example, only five rivers of sixth order or higher are included in these reviews. These large rivers indeed tend to receive lower amounts of litterfall per unit surface area than headwaters, but inputs to large rivers can nevertheless be significant. as has been shown for two 7th-order rivers. The River McKenzie (Oregon, USA) received an annual leaf input of $218 \mathrm{~g} \mathrm{~m}^{-2}$ (calculated from CUMMINS et al., 1983, in WEBSTER \& MEYER, 1997), and the direct. aerial, input of litter from the

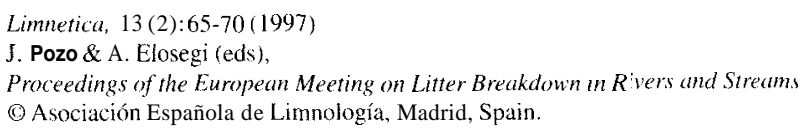

riparian forest to the River Garonne (S-W France) was estimated to be $42 \mathrm{~g} \mathrm{~m}^{-2} \mathrm{y}^{-1}$ (CHAUVET \& JEAN-LOUIS, 1988) which corresponds to almost $10 \%$ of the mean value for small woodland streams (BIRD \& KAUSHIK, 1981). Moreover, the litter input to the River Garonne was calculated to exceed by three times the autochthonous production of aquatic macrophytes (CHAUVET, 1994). Like in streams, leaf litter entering a large river is expected to be subject to various abiotic and biotic processes causing its decomposition. However, large rivers and streams can differ in some traits, either related to their riparian leaf species, environment or biota, which are potentially determining for the fate of leaf litter. For instance, some observations suggest that the implication of macroinvertebratec in leaf decomposition tends to be less critical in large rivers than in headwater streams (MATHEWS \& KOWALCZEWSKI, 1969: CHERGUI \& PATTEE, 1988).

The objective of this paper is to review the studies on leaf litter decomposition conducted in the River Garonne over the last fifteen years, in order to highlight come particuiarities of the decomposition process when occurring in a large river system. This review doesn't aim to deal with studies on other large rivers. Although limited to the River Garonne and its flood- 
plain, this rcview however intends to tackle a number of factorc which could also be relevant for moct large rivers from temperate regions.

\section{LEAF SPECIES}

Large rivers like the River Garonne typically flow in lowland areac while a major proportion of their headwaters is located in mountainous regions. In addition to physical discrepanciec between both lotic habitats, thic results in differences in the nature of leaf litter inputs originating from the riparian forests deveioped along these rivers. A shift in litter quality along the river continuum can be obcerved: coftwood species tend to dominate in the riparian forests of large river systems and hardwood species like oaks and beech as well as conifers are generally more abundant along mountainouc low-order streams. For instance, the three major species of the alluvial forect of the River Garonne are Salix alba L., Populus nigra L. and Alnus glutinosa Gaertn. (CHAUVET, 1987; CHAUVET \& JEANLOUIS, 1988) while many mountainous ctreains of the River Garonne basin are typically influenced by a beech forest. The quality of leaf litter may be illustrated by its $\mathrm{C}: \mathrm{N}$ ratio which ranges from about 20-40 for softwood species to 60 or more for hardwood species and conifers (fig. 1). Since decomposition rates have been demonstrated to be negatively related to the ini-

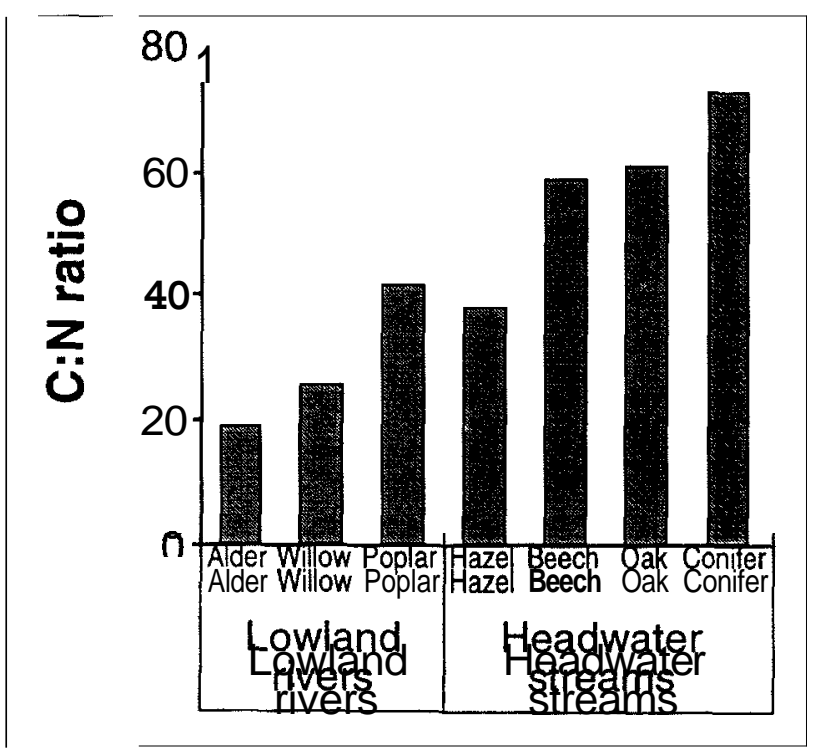

Figure 1. Initial C:N ratio of leaf littcr of different tree species: alder (Alnus glutinosa Gaertn.), willow (Salix Alba L.), poplar (Populus gr nigra), hazel (Corylus avellana L.), beech (Fagus sylvatica L.), oak (several sp. of Qtuerctus). conifer (several sp.). Average values from CHAUVET (1987), GESSNER \& CHAUVET (1994) and other literature sources tial C:N ratio of leaf litter (TAYLOR et al.. 1989), the decomposition of softwood species is expected to be faster than that of the upstream species. Note that decomposition rates have also been shown to be correlated with other factors including lignin content of leaf litter (GESSNER \& CHAUVET, 1994), and that rankings of species according to their $\mathrm{C}: \mathrm{N}$ ratio or their lignin content are about consistent. The combination of these differences in decomposition rates and the contrasting distribution of tree speciec along the river continuum ic probably crucial for the rriatter and energy budgets when the river functioning is examined at the river network level.

\section{PHYSICAL HETEROGENEITY OF RIVER SYSTEMS}

River corridors are generally bound by transitional areas, or ecotonec, between the aquatic and terrestrial ecosystems (NAIMAN \& DÉCAMPS, 1990). Current theoriec (JUNK et al., 1989; SEDELL et al., 1989; THORP \& DELONG, 1994) stressed the importance of these zones which, depending on the extent of the river floodplain, may provide a major portion of carbon to the aquatic food web through local autochthonouc production and litterfall inputs. In addition to being highly productive and supplying considerable amounts of organic matter to the river systein, these areas are influenced by flooding and are subject to suhstantial spatial and temporal Ructuations in such phycical parameter., as soil water content and oxygen concentration. A study was conducted on the river margins of the River Garonne to examine the influence of this heterogeneity on the fate of leaf litter during decomposition (CHAUVET, 1988). Willow leaves were exposed on five representative sites along a transect of the River Garonne: fast running water, slow flowing water, standing water, floodable soil and non-floodable soil. A striking result of this study was the strong overiap of the range of decomposition rates from the aquatic and "terrestrial" habitats, aithough this was partly due to a high variation within both environments (fig. 2). In both habitats, the oxygen level appeared to control the decomposition rate, with the most rapid decomposition occurring when oxygen was not limiting. The river bank which was subject to an $83 \mathrm{~d}$-flooding period exhibited the slowest decomposition. At this site, the pattern of leaf mass loss revealed a marked slowing down as soon as leaf litter was buried by sediment deposits after the spring floods. Such a burial process, leading to a storage of organic matter in river margins, typically occurs in non regulated rivers whose natural flooding processes have been preserved (MAYACK et al., 1989). A consequence of this spatial variability of physical parameters could be a patchy distribution of litter decomposi- 


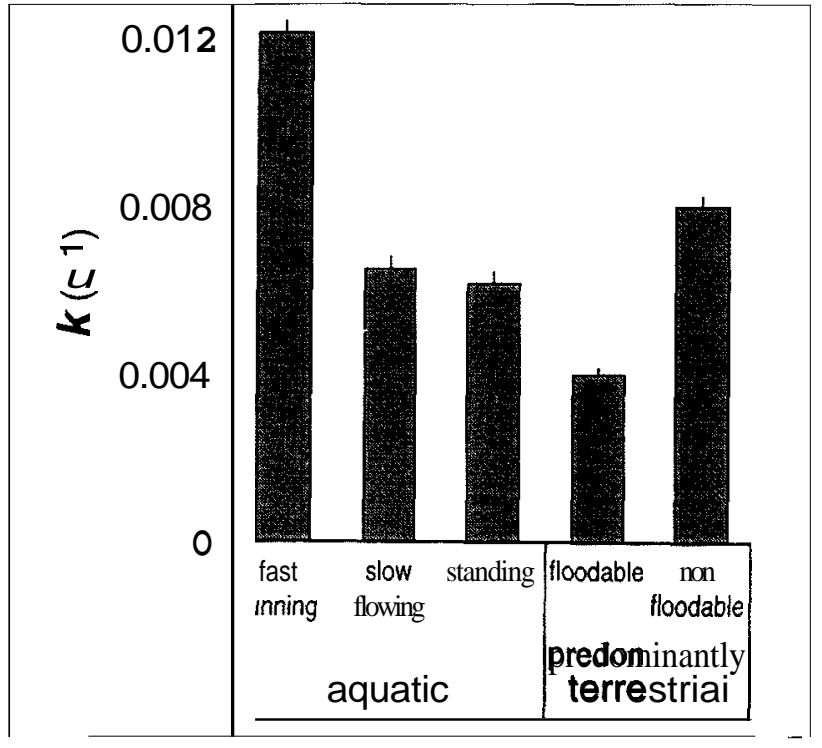

Figure 2. Decomposition rate $(k)$ of willow leaf litter in different locations along a transect of the River Garonne $+95 \%$ asymptotic confidence limit (from CHAUVET, 1988)

tion patterns and rates within large river floodplains

\section{ROLE OF INVERTEBRATES}

According to current theory, the aquatic invertebrate community changes along the river continuum from one dominated by shredders and collectors in headwaters to one dominated by collectors in high-order reaches (MINSHALL et al., 1983). Due to the implication of shredders in leaf litter decompocition, both decomposition rates and patterns are obviously expected to be affected by such a distribution. In order to document these changes. we cornpared the decompocition of leaf litter in two contrasting running waters located within the same river network, a 3rd-order mountain stream (The Touyre) and the 7thorder River Garonne (CHAUVET et al., 1993). Beech (Fagus sylvatica L.) and willow (Salix alba) leaves, i.e. the dominant species indigenouc to the Touyre and River Garonne, respectively, were incubated in both streams. The same methods were used for both sites. with $4-\mathrm{g}$ portions of dried leaves being enclosed in mesh bags (4-mm mesh) and submerged in the streams. Both willow and beech decomposed at lower rates in the large river, but within both streams willow decomposed faster than beech and this leaf effect was stronger than the strearn effect (fig. 3). Although charactericed by slower leaf litter decomposition, the large river exhibited consistently higher total invertebratc densities and biomass associated with the decomposing leaves and a higher proportion of shredders (in

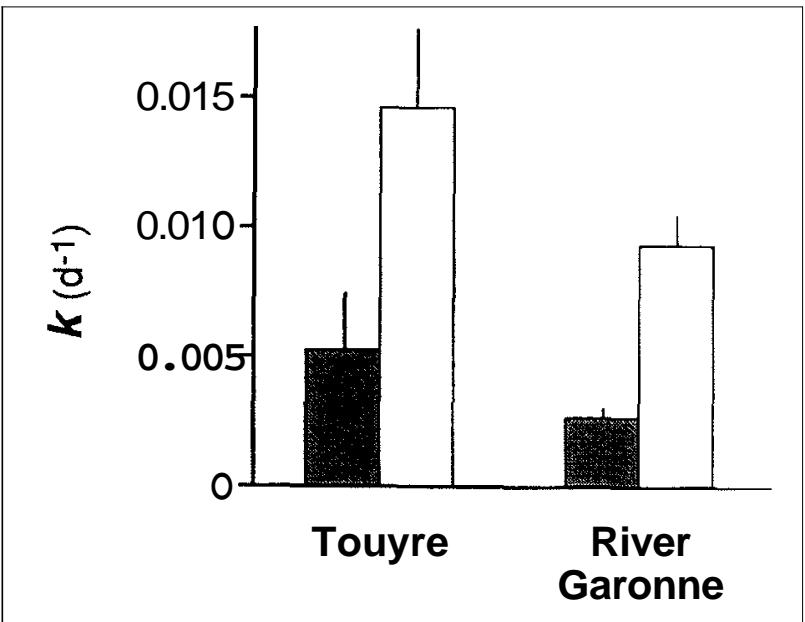

Figure 3. Decomposition rate of beech $(\square)$ and willow $(U)$ leaves in a 3 rd-order stream and a 7 th-order river $+95 \%$ asymptotic confidence limit (from CHAUVET et al., 1993).
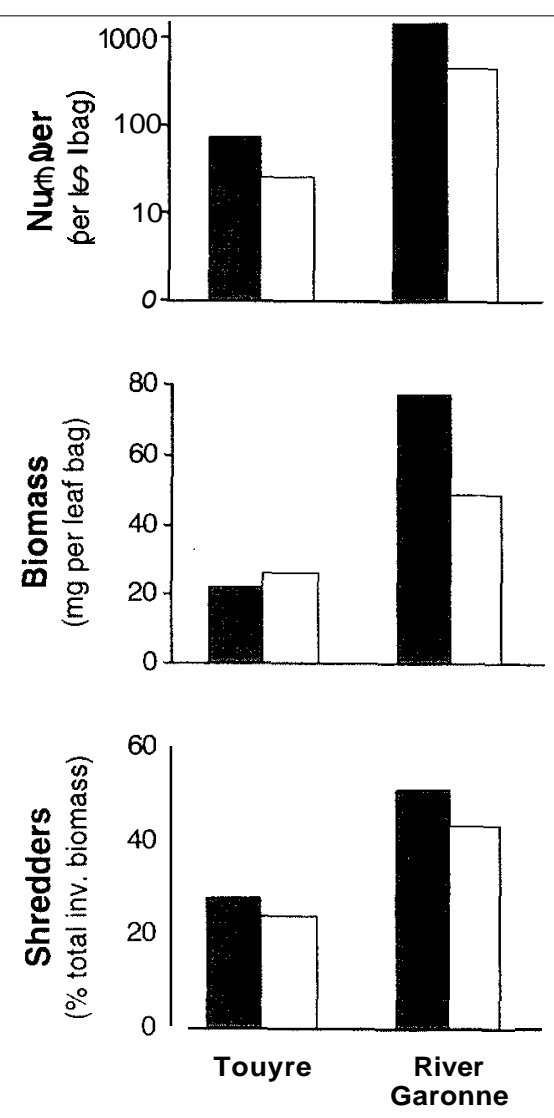

Figure 4. Number and biomass of invertebrates and percentage of shredders in the invertebrate assemblage associated with beech (-) and willow (]) leaves decomposing in a 3rd-order strearn and a 7th-order river (average values over 6 months of decomposition; from CHAUVET et al. 1993) 
terms of biomass) in these assemblages (fig. 4). The high numbers in the River Garonne were mainly due to the extremely numerous oligochaetes, particularly small naidids which feed on FPOM and probably used litter accumulations primarily as an habitat. In terms of biomass, unexpectedly, the major component of the invertebrate assemblages on leaves in the River Garonne were shredders, which represented about $50 \%$ of the average total. The dominant taxa were the crustaceans Asellus aquaticus L. and Gammarus cf. pulex L., a feature also recorded in another large river in Southeastern France, the River Rhône (CHERGUI \& PATTEE, 1988). In the 3rd-order stream investigated by CHAUVET et al. (1993), the shredders were represented by several plecopteran and trichopteran taxa and accounted for only $30 \%$ of the invertebrate biomass, probably due to a high feeding pressure of invertebrate predators on the shredder community. However, in a similar study conducted in another year with alder leaf litter and only a few hundred meters upstream, shredders largely dominated the invertebrate community (GESSNER \& DOBSON, 1993). Note that all these observations only concerned the assemblages on decomposing leaves, and not the whole invertebrate community from the river. While this denotes some possible variation in invertebrate assemblages between years and stretches within the same stream, all this suggests that the occurrence of shredders on leaves decomposing in a large river may be as high than that occurring in a low-order stream, a feature which contrasts with current observations or hypotheses on the distribution of macroinvertebrates along the river continuum. This finding is however consistent with recent theories which emphasize the importance of large particulate organic matter, including riparian leaf litter, in the functioning of large river ecosystems (e.g., THORP \&

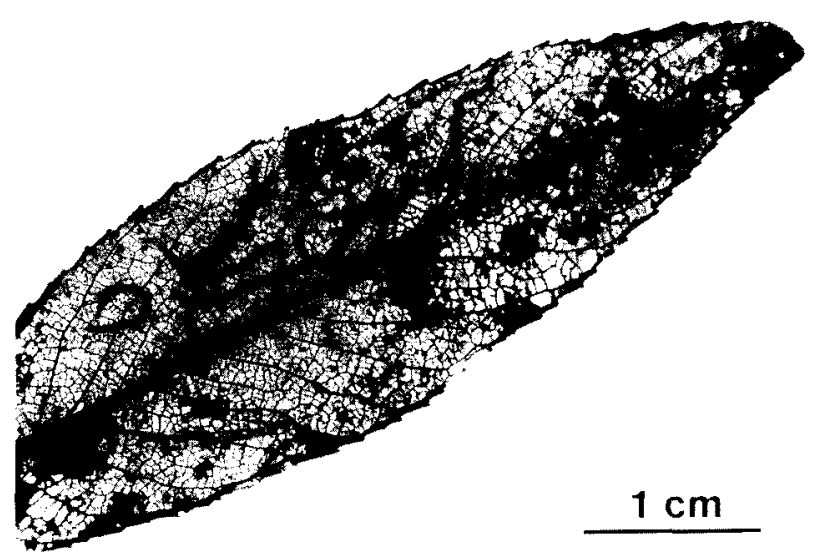

Figure 5. A willow leaf after 5 months of decomposition in the River Garonne. Note the presence of tubificid oligochaetes inside the leaf matrix.
DELONG, 1994). Whether or not this importance of shredders is typical of large rivers with unconstricted channel and extended floodplain, remains unknown; this question desserves further attention.

Another striking trait of the invertebrate assemblages on leaves in the River Garonne was the abundance of tubificid oligochaetes, which during late stages of decomposition represented up to $50 \%$ of the total invertebrate biomass. Tubificids only occurred after 4-5 months of immersion on substantially degraded leaves, i.e. when the leaf epidermis peeled off and the leaf tissue was fragmented into several layers. These worms were regularly encountered even inside the leaf matrix, which suggests that they were feeding on leaf parenchyma cells and the bacteria associated with them (fig. 5). Consequently it was suggested that tubificids may enhance leaf fragmentation by their movement and feeding activity (as shown in a laboratory experiment; CHAUVET, unpublished data), thereby possibly increasing the incorporation of plant organic matter into the river sediment.

\section{MICROBIAL IMPLICATION}

Although supporting a high biomass of shredders, leaf litter decomposed at slower rates in the River Garonne than in the headwater stream, suggesting a lower contribution of other agents, i.e. microorganisms, in the breakdown process or a limitation of abiotic fragmentation. Therefore, we attempted to evaluate directly the microbial biomass associated with three leaf species decomposing in the River Garonne: willow (Salix alba), poplar (Populus nigra) and plane (Platanus hybrida Brot) (BALDY et al., 1995). Bacterial biomass was estimated from cell counts combined with measurements of bacterial cell biovolumes while fungal biomass was determined from leaf ergosterol contents, species-specific conversion factors and the relative abundance of species in the fungal community (GESSNER, 1997). In addition, sporulation rates of aquatic hyphomycetes were determined by short incubations conducted at different decomposition stages. Bacteria reached densities of almost $10^{8}$ cells per mg of leaf ash free dry mass (AFDM) after 1-2 months of exposure in the river. Expressed relative to the initial amount of leaf carbon, the bacterial biomass represented a maximum of $0.3-0.5 \%$ of the leaf detritus mass. The mycelial biomass attained peaks of $5 \%$ (plane) to $10 \%$ (poplar) of detrital carbon after 1-2 months, values quite consistent with those reported from leaf litter decomposing in headwaters (GESSNER, 1997). Peak sporulation rates on leaves in the River Garonne were in the range 1.2-1.4 conidia $\mu \mathrm{g}^{-1} \mathrm{~d}^{-1}$ with a value for plane leaf litter identical to that determined for the same leaf species in the 
headwater of the River Garonne bacin (GESSNER \& CHAUVET, 1994). Fungi accounted for $88-100 \%$ (mean $96 \%$ ) of the microbial (fungal plus bacterial) biomass in leaf litter decomposing in the large river. Such a dominance of fungal over bacterial biomass has been reported from small streamc (FINDLAY \& ARSUFFI, 1989; WEYERS \& SUBERKROPP, 1996; BALDY \& GESSNER. 1997) but was unexpected in large rivers. Given the amount of fungal biomass produced as mycelium and conidia, fungi have been calculated to contribute for about half of the overall carbon loss during periodc of highest fungal activity in the River Garonne. Taken together, thece results clearly demonstrate a pre-eminent role of fungi in the leaf decomposition process, which does not fundamentally differ from that reported from small streams. The slower decomposition observed in the River Garonne could then not be attributed to a lower microbial activity, but rather to a reduced loss of particles by mechanical breakage. The leaves decomposing in the deep and clow-flowing river were probably not subject to any chear stress while the physical abrasion and erosion may have accounted for a substantial leaf mass loss in the mountain stream, especially at later stages of decomposition and during periods of spatec.

Although not the only fungi present, aquatic hyphomycetes appear to dominate the fungal accemblages on leaf litter in the River Garonne (CHAUVET et al.. 1986; BALDY, 1996). Species establishment is somewhat similar to that observed in the headwater mountain stream (GESSNER et al., 1993) with early decomposition stages dominated by Flagellospora curvila Ingold and the latest stages characterized by Clavariopsis aquatica De Wild. Three other species. namely Anguillospora longissima (Sacc. et Sidow) Ingold, Tetracladium marchalianum De Wild. and Lunulospora curvula Ingold, were common colonizers during intermediate and late stages. The two latter cpecies were not, or only very rarely. obcerved in the mountain stream while some species present there were not found in the River Garonne. This change in species assemblages, possibly due, in part, to different temperature regimes of the two streams ( see CHAUVET \& SUBERKROPP, 1998), constitutes the only major difference between communitiec developing in both streams.

\section{CONCLUSION}

Lcaf litter originated from the riparian vegetation can be an important source of organic matter even for large rivers like the River Garonne. As the riparian forest of such rivers is essentially compoced of softwood tree species. decomposition of leaf litter tends to be enhanced when coinpnred to that occurring in headwater streams mostly influenced by inputs from hardwood and coniferous cpecies. Due to their phycical heterogeneity, large river cystems are generally subject to a wide range of environmental conditions, inducing variable decomposition dynamics. For example, sediment deposition, a typical phenomenon occurring in large river cystems, can slow down decomposition substantially. With regard to the biological activity in leaf decompocition, large rivers do not seem to function differently from low-order streams, since the implication of both microfungi and shredders was found to be similar in a headwater stream. The River Garonne was also characterized by the occurrence of tubificid wormc which could enhance leaf fragmentation and the incorporation of organic inatter into river sediments.

\section{ACKNOWLEDGEMENTS}

I am inuch obliged to Jesús Pozo for kindly inviting me to attend the European Meeting on Litter Breakdown in Rivers and Streams. I am grateful to M.O. Gessner. M. Dobson and D. Dudgeon for critical commentary on the manuscript. The original research reported in this paper was partly supported by the European Commission (DG XII, contract $n^{\circ}$ EV5VCT920 100) and C.C.R.D.T.- Région Midi-Pyrénées (contracts $n^{\circ}$ 9300082/9307903/9407898).

\section{REFERENCES}

BALDY, V.. 1996. Décomposition des litières en milieu, fluvial tempéré = bilan carboné du processus - biomasses et produ<tions ba<tériennes et fongiyues associr'es. These de Doctorat. Université de Toulouse, Toulouse.

BALDY. V. \& M.O. GESSNER, 1997. Towards a budget of leaf litter decomposition in a first-order woodland stream. C. $R$. Acad. Sci., Paris, Sciences de la vie/Life Sciences. 320: 747758.

BALDY, V., M.O. GESSNER \& E. CHAUVET. 1995. Bacteria, fungi and the breakdown of leaf litter in a large river. Oikos. 74: 93-102.

BENFIELD, E.F., 1997. Comparisons of litterfall input to streams. In: Stream organic matter budgets (J.R. WEBSTER \& J.L. MEYER, eds.): 104-108. J. N. Am. Benthol. Soc., 16: 3161.

BIRD. G.A. \& K. KAUSHIK, 1981. Coarse particulate organic matter in streams. In: Perspectives in running water ecology (M.A. LOCK \& D.D. WILLIAMS, eds.): 41-68. Plenum Press. New-York.

CHAUVET. E.. 1987. Changes in the chemical composition of alder. poplar, aiid willow leaves during decoinposition in a 
river. Hydrobiologia, 148: 35-44.

CHAUVET, E., 1988. Influence of the environment on willow leaf litter decomposition in the alluvial corridor of the Garonne River. Arch. Hydrobiol., 1 12: 371-386.

CHAUVET, E., 1994. Production and decomposition of aquatic macrophytes in the River Garonne. Verh. Int. Ver. Limnol., 25: 2305-2308.

CHAUVET, E. \& A.M. JEAN-LOUIS, 1988. Production de litiere de la ripisylve de la Garonne et apport au fleuve. Acta Oecol., Oecol. Gen., 9: 265-279.

CHAUVET, E., J. MERCÉ \& A.M. JEAN-LOUIS, 1986. Hyphomycètes aquatiques colonisant les feuilles de Salix alba L. Bull. Soc. Mycol. Fr., 102:347-351.

CHAUVET, E., N. GIANI, \& M.O. GESSNER, 1993. Breakdown and invertebrate colonization of leaf litter in two contrasting streamc: significance of oligochaetes in a large river. Can. J. Fish. aquat. Sci., 50: 488-495.

CHAUVET, E. \& K. SUBERKROPP, 1998. Temperature and cporulation of aquatic hyphomycetes. Appl. Environ. Microbiol., 64: 1522-1525.

CHERGUI, H. \& E. PATTEE, 1988. The impact of benthic invertebrates on the breakdown of poplar leaves in the network of a large European river. Arch. Hydrobiol., 113: 15-25.

CUMMINS, K.W., J.R. SEDELL, F.J. SWANSON, G.W. MINSHALL, S.G. FISHER, C.E. CUSHING, R.C. PETERSEN \& R.L. VANNOTE, 1983. Organic matter budgets for stream ecosystems: problems in their evaluation. In: Stream Ecology: Application and testing of general ecological theory (J.R. BARNES \& G.W. MINSHALL., eds.): 299-353. Plenum Press, New York.

CUMMINS, K.W., M.A. WILZBACH, D.M. GATES, J.B. PERRY \& W.B. TALIAFERRO, 1989. Shredders and riparian vegetation. Leaf litter that falls into streams influences communities of stream invertebrates. BioScience, 39: 24-30.

FINDLAY, S.E.G. \& T.L. ARSUFFI, 1989. Microbial growth and detritus transformations during decomposition of leaf litter in a stream. Freshwat. Biol., 21: 261-269.

GESSNER, M.O., 1997. Fungal biomass, production and sporulation associated with particulate organic matter in streams. In: Proceedings of the European Meeting on litter Breukdown in Rivers and Streams (J. POZO \& A. ELOSEGI, edc.): 33-44. Limnetica, 13(2): 1- 102.

GESSNER, M.O. \& E. CHAUVET, 1994. Importance of stream microfungi in controlling breakdown rates of leaf litter. Ecology, 75: 1807-1817.

GESSNER, M.O. \& M. DOBSON, 1993. Colonisatiori of fresh and dried leaf litter by lotic macroinvertebrates. Arch. Hydrobiol., 127: 141-149.
GESSNER, M.O., M. THOMAS, A.-M. JEAN-LOUIS \& E. CHAUVET, 1993. Stable successional patterns of aquatic hyphomycetec on leaves decaying in a summer cool stream. Mycol. Res.. 97: 163-172.

HYNES, H.B.N., 1963. lmported organic matter and secondary productivity in streams. Proc. 16th Int. Congr. Zool., 3: 324-329.

JUNK, W.J., P.B. BAYLEY \& R.E. SPARKS, 1989. The flood pulse concept in river-floodplain systems. In: Proceedings of the International Lurge River Symposium (D.P. DODGE, ed.): 110-127. Can. Spec. Publ. Fish. Aquat. Sci., 106.

MATHEWS, C.P. \& A. KOWALCZEWSKI, 1969. The disappearance of leaf litter and its contribution to production in the river Thames. J. Ecol., 57: 543-552.

MAYACK, D.T., J.H. THORP, \& M. COTHRAN, 1989. Effects of burial and floodplain retention on stream processing of allochthonous litter. Oikos, 54: 378-388.

MINSHALL, G.W., R.C. PETERSEN, K.W. CUMMINS, T.L. BOTT, J.R. SEDELL, C.E. CUSHING \& R.L. VANNOTE, 1983. Interbiome comparison of stream ecosystem dynamics. Ecol. Monogr., 53: 1-25.

NAIMAN, R.J. \& H. DÉCAMPS, 1990. The ecology and management of aquatic-terrestrial ecotones. UNESCO, Paric \& Parthenon Publ., New Jersey.

TAYLOR, B.R., D. PARKINSON \& W.F.J. PARSONS, 1989. Nitrogen and lignin content as predictors of litter decay rates. A microcosm test. Ecology, 70: 97-104.

SEDELL, J.R., J.E. RICHEY \& F.J. SWANSON, 1989. The river continuum concept: a basis for the expected ecosystem behavior of very large rivers? In: Proceedings of the International Lurge River Symposium (D.P. DODGE, ed.): 49 55. Can. Spec. Publ. Fish. Aquat. Sci., 106.

THORP, J.H. \& M.D. DELONG, 1994. The riverine productivity model: an heuristic view of carbon sources and organic processing in large river ecosystems. Oikos, 70: 305-308.

VANNOTE, R.J., G.W. MINSHALL, K.W. CUMMINS, J.R. SEDELL \& C.E. CUSHING, 1980. The river continuum concept. Can. J. Fish. aquat. Sci., 37: 130-137.

WEBSTER, J. \& J. MEYER, 1997. Stream organic matter budgets. J. N. Am. Benthol. Soc., 16: 3-161.

WEIGELHOFER, G. \& J.A. WARINGER, 1994. Allochthonous input of coarse particulate organic matter (CPOM) in a first to fourth order Austrian forest stream. Int. Rev. ges. Hydrobiol., 79: 461-471.

WEYERS, H.S. \& K. SUBERKROPP, 1996. Fungal and bacterial production during the breakdown of yellow poplar leaves in 2 streams. J. N. Am. Benthol. Soc., 15: 408-420. 